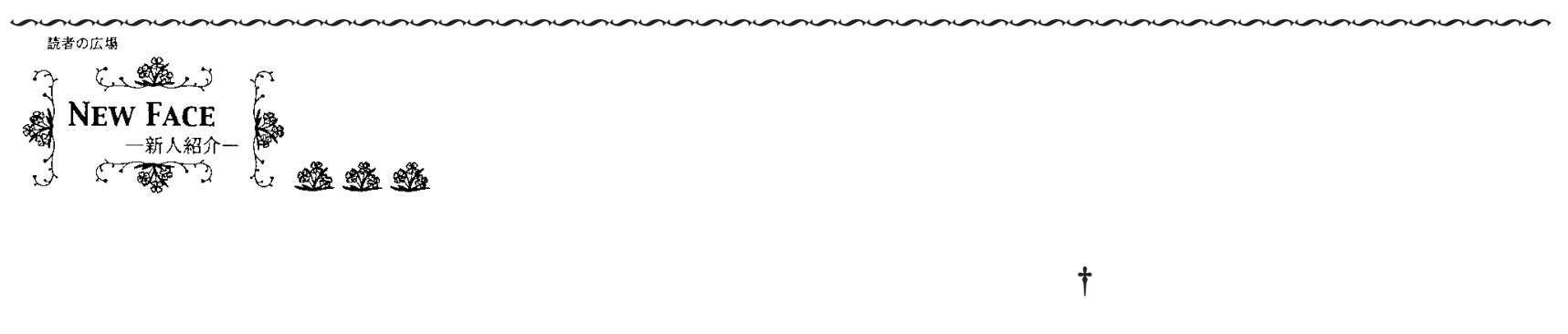

\title{
Evaluation of Biodegradability of Polymeric Materials by Analytical Pyrolysis and Mass Spectrometry
}

\author{
佐 藤 浩 昭* \\ Hiroaki SATO
}

(Received October 23, 2002; Accepted November 5, 2002)

\begin{abstract}
In order to develop a noble evaluation method for biodegradability of polymeric materials, various biodegradable polymers have been characterized mainly by using pyrolysis-gas chromatography (Py-GC) and matrixassisted laser desorption/ionization-mass spectrometry (MALDI-MS). First, the degree of biodegradation of poly(butylene succinate-co-butylene adipate) (PBSA) film samples during the soil burial degradation test was evaluated by Py-GC. This technique was further applied to evaluate the compositional change of biodegradable polymer blends during enzymatic degradation test. On the other hand, enzymatic degradation behavior of a biodegradable polyester with a controlled terminal structure was monitored by MALDI-MS mainly focused on the changes in molecular weight distribution and terminal structure. Finally, biodegradation intermediates of nonionic surfactant were characterized by MALDI-MS. By using ${ }^{18}$ O-labelled water as an incubation medium, detailed biodegradation mechanisms of the surfactant were proposed.
\end{abstract}

\section{1. はじめに}

自然環境中で微生物の作用によって分解される生分解性 高分子材料は, 優れた環境調和型材料として, 最近大きく 注目されている. 従来, 弚の生分解性は, 重量変化や形状 の変化などの巨視的な変化，機械的強度などの物理的な変 化，および分解過程における $\mathrm{CO}_{2}$ の発生量などに基づく 生化学的な変化などによって評価されることが多く, 生分 解過程における高分子鎖の微妙な化学構造変化を解析する ことは困難であった.

そこで, 筆者らは, 分子構造と生分解性の相関を解析す ることにより, 材料として必要な諸物性と, 使用される環 境に応じた生分解特性を兼ね備えた, 優れた環境調和型材 料の設計・開発に有用な情報を提供できるのではないかと 考え, 生分解性高分子材料の分解挙動を, 分子レベルて解 析する新しい解析手法の開発に取り組んできた。 弚の解析

* (独)産業技術総合研究所 環境管理研究部門 (业305-8569 つくば市小野川 16-1)

Institute for Environmental Management Technology, National Institute of Advanced Industrial Science and Technology (AIST) (16-1 Onogawa, Tsukuba, Ibaraki 3058569, Japan)
手段の一つとして用いてきた熱分解ガスクロマトグラ フィー (Py-GC) は, 微量の試料 $(\sim 100 \mu \mathrm{g})$ を瞬間的に熱 分解し, 生じたフラグメントを $\mathrm{GC}$ 分析することによっ て, 高分子化合物の微細化学構造に関する情報を定量的に 解析することができる特徵を有している．また，もう一つ の解析手段として用いてきた，マトリックス支援レーザー 脱離イオン化-質量分析法 (MALDI-MS) は, Py-GC とは 対照的に, 高分子鎖をほとんど分解することなくイオン化 し, 主として分子量関連イオンピークから構成されるマス スペクトルを観測することによって，高分子鎖の分子量分 布や末端基構造などの解析を行うことができる ${ }^{11}$. 本稿で は, こうした解析手法を相補的に用いて行ってきた，生分 解性高分子材料の生分解過程における微細化学構造の变化 を解析した研究例として, 生分解性ポリエステルと非イオ ン系界面活性剂の生分解挙動を解析した最近の研究内容を 簡単に紹介する.

\section{2. 土中埋没試験により生分解したポリエステルの Py-GCによる分解性評価 ${ }^{2)}$}

生分解性高分子材料の環境適合性を評価するための分解 試験法として, フィルム状の高分子材料を微生物か每繁殖し ている土中に埋没し，一定期間が経過してからフィルム片

\footnotetext{
† Congratulations on winning the 2002 Nobel Prize

Prof. John B. Fenn and Dr. Koichi Tanaka were jointly awarded this year's Nobel Prize in Chemistry.
} 
を回収して分解特性を解析する，土中埋没試験法がよく用 いられる. この試験法では, 試料片の形態変化や重量変化 などの巨視的な変化に基ついて生分解性か評価されること が一般的であるが, 本研究では, 土中埋没試験を行った後 に回収された残存試料を Py-GC 測定し, 微細化学構造の 変化を詳細に解析することによって試料の生分解の進行度 を評価する, 新しい生分解性評価法の開発を試みた。

試料には, 市販されている脂肪族ポリエステル共重合体 (商品名 Bionolle \#3000, 昭和高分子) を用いた. この試料 は, コハク酸ブチルとアジピン酸ブチルからなるランダム 共重合体であり, 鎖長を延長するためにへキサメチレンジ イソシアネートがウレタン結合を介して微量導入されてい ることが， ${ }^{1} \mathrm{H}$ NMR 測定などによって確認されている. ま た, 高分子鎖の末端は, 基本的には水酸基およびカルボキ シル基であるが, 一部がアルキル基に変性していることが 報告されている.

土中埋没試験法による生分解試験は, 名古屋大学実習農 場において堆肥を 10 年与え続けた土に, 最大 60 日間, フィルム状の試料片を埋没して行った. 所定の時間か経過 後, 土中に残留した試料フィルムを回収し, 水洗・乾燥し た後に Py-GC 測定に供した. Py-GC 測定では, 約 $100 \mu \mathrm{g}$ の試料を, $\mathrm{GC}$ 試料注入口に取り付けた小型熱分解装置内 で, $500^{\circ} \mathrm{C}$ て瞬間的に熱分解し, 生じた熱分解生成物を才 ンラインで $\mathrm{GC}$ 分析した.

Fig. 1 に, 生分解試験前の試料から得られたパイログ ラム（熱分解ガスクロマトグラム）を示す. パイログラム 上には，主鎖の熱分解に起因するコハク酸エステル類 (S) やアジピン酸エステル類 $(\mathrm{A})$ が主成分として生成し, 产の ほか, 微量成分としてイソシアネート部分から生じた熱分 解生成物 (N) および高分子末端の異常構造である末端アル キル基部分を起源とすると考えられるアルキルエステル類 $\left(\mathrm{A}_{\mathrm{E}}\right)$ か観測された. 次に, 生分解試験を行った試料につい て, 各ピークの強度変化を調べたところ, 主鎖より生じる 熱分解生成物 ( $\mathrm{S}, \mathrm{A}$ ，および $\mathrm{N}$ ) の相対ピーク強度の変化は ほとんど観測されなかったが, 末端の異常構造を反映する $\mathrm{A}_{\mathrm{E}}$ の相対ピーク強度が, 生分解試験の進行に伴い, フィル 么試料の回収重量の減少と良い相関をもって減少している ことがわかった. 乥こで, $\mathrm{A}_{\mathrm{E}}$ の相対ピーク強度を指標にし

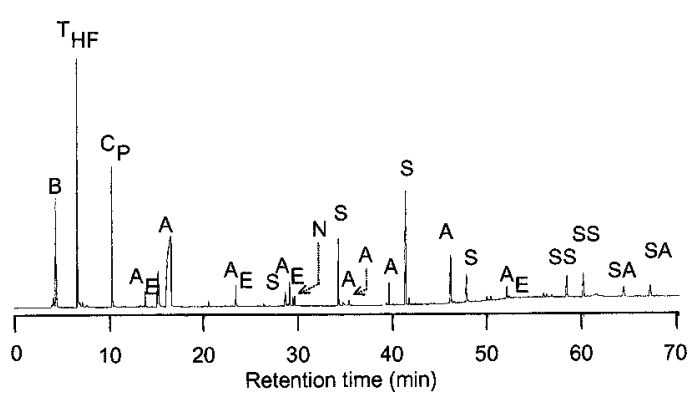

Fig. 1. Typical pyrogram of biodegradable polyester (Bionolle $\$ 3000$ ) at $400^{\circ} \mathrm{C}$. (S, succinates; A, adipates; $\mathrm{N}$, hexamethylene diisocyanate; $\mathrm{A}_{\mathrm{E}}$, fatty-acid esters; B, butadiene; THF, tetrahydrofuran; $\mathrm{Cp}$, cyclopentanone.)
て, 生分解させた同一試料フィルム内での局所的な生分解 の進行度の評価に応用することを試みた。ここでは, 生分 解試験後に回収されたフィルム上で, 外観上, 生分解の進 行度がかなり異なっていると推定される複数の部位から, 直径 $2 \mathrm{~mm}$ の測定試料を採取し, Py-GC 測定した. 兴の結 果, 回収フィルム上で半透明の部分では, $\mathrm{A}_{\mathrm{E}}$ の相対ピーク 強度は元の試料とほほ等しかったが, 白濁した部分では光 の強度が約 $2 / 3$ に減少し, 穴の周囲ではほぼ半減している ことがわかり，Py-GC 測定によって， Bionolle \#3000の 局所的な生分解の進行度を半定量的に評価することができ た.

\section{3. 生分解性ポリマーブレンドの反応熱分解 GC による生分解性評価3)}

生分解性高分子材料は, 単独の成分では目的とする機械 的強度などの諸物性や生分解性を達成できない場合が多い ため, こうした特性を制御するために, 複数の生分解性高 分子をブレンドしたハイブリッド材料の開発が試みられて いる. こうしたハイブリッド材料の設計・開発に際して は, 弚の生分解過程における化学構造や組成变化を詳細に 解析することか浗められている，弚こで本研究では，代表 的な生分解性ポリマーの一種であり, 農業用シートや包装 容器などの素材として工業的にも利用され始めている, ポ リ-L-乳酸 (PLA) とポリ ( -カプロラクトン) (PCL) とのブ レンドを試料として酵素分解試験を行い，分解の進行に伴 うブレンド組成の変化を, 試料に有機アルカリ試薬を共存 させて熱分解する「反応熱分解 $\mathrm{GC} 」 に よ り$ 求め, 分解過程 におけるブレンド試料の 構造変化を解析することを試み た.

ここでは, 溶媒キャスト法によって PLA と PCL を重量 比で50/50（モノマーモル比：61/39）となるブレンド試 料を調製した. このブレンド試料は, PLA 相の中に PCL 相が分散した「海島」型の相分離構造をもつ不均一なブレ ンド系である. 酵素分解試験は, エステル分解酵素である Pseudomonas sp. 由来のコレステロールエステラーゼを用 い, リン酸緩衝液 ( $\mathrm{pH}$ 7.0) 中で最大 48 時間にわたって 行った. なお，この酵素は PLA に対する分解能力をほと んどもたないことがわかっている.

通常，ポリエステルを熱エネルギーのみで分解すると， しばしば GC 分析が困難な高沸点・高極性の熱分解生成物 が生じる，乥こで，ポリエステル試料に水酸化テトラメチ ルアンモニウム (TMAH) などの有機アルカリ試薬を共存 させて熱分解する「反応熱分解法」を用いると, エステル 結合が選択的に加水分解されると同時に高効率でメチル誘 導体化され，高分子鎖の構造情報を正確に反映したパイロ グラムか観測されるようになる. 本実験では，約 $50 \mu \mathrm{g} の$ ブレンド試料に TMAHの $25 \%$ メタノール溶液を $4 \mu \mathrm{L}$ 添加し, $350^{\circ} \mathrm{C}$ て目舜間的な試料の反応熱分解を行った.

Fig. 2 に, TMAH 共存下での反応熱分解 GC で得られ た酵素分解試験前のブレンド試料のパイログラムを示す. パイログラム上には, PLA 成分からの主生成物である乳 


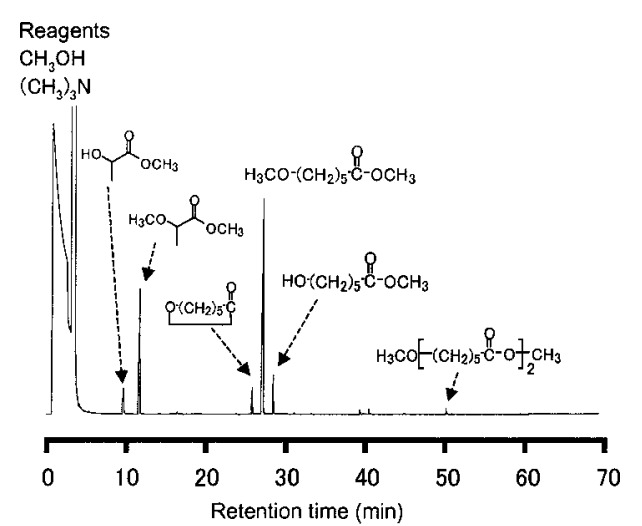

Fig. 2. Typical pyrogram of biodegradable polymer blend (PLA/PCL) at $350^{\circ} \mathrm{C}$ in the presence of TMAH.

酸のメチルエステル誘導体と, PCL 成分からの主生成物 であるカプロラクトンおよびカプロン酸のメチル誘導体の ピークが高強度で観測されている。 これらの各ピーク強度 を基にして, 酵素分解試験後に回収された残留試料のブレ ンド組成の変化を調べたところ, 酵素分解の進行に伴って PCL 成分の組成が徐々に減少していくことがわかった.

これは, 本酵素がPLA に対する分解性をもっていないた めであるが, 各試料の回収重量から求めた各構成成分の正 味の分解率を算出したところ, PLA 成分もある程度分解 していることがわかった. 弚の理由として, 海島型の相分 離構造をもつブレンド試料内で,「海」に相当する PCL 相 に取り込まれた「島」のPLA 相の一部が，周囲の PCL 成 分の分解によって剥離したために, PLA 成分も見かけ上 分解したように観測されたのであると推測された。

\section{MALDI-MS によるポリカプロラクトンの 生分解挙動の解析 ${ }^{4}$}

生分解性高分子材料の分解パターンは, 分子鎖中でラン ダムに切断が起こる「endo 型」と, 高分子鎖の末端から順 次分解反応が起こる「exo 型」の二つのタイプに大別する ことができる. 特に後者の場合, 高分子鎖の末端化学構造 は, 生分解特性に大きく影響するであろう. しかしながら, 従来は, 生分解過程での平均分子量の変化や分解生成物の 生成量の変化から, 反応速度論的な解析を行うことによっ て, 間接的に分解特性の判定がなされる場合が多く, 簡便 かつ正確な評価手法の開発が望まれている. 乥こで本研究 では，PCL をモデル試料に用い，MALDI-MS によって， PCL を酵素分解処理した後に回収された残存物の末端化 学構造や分子量分布の变化を観測し, 兴の生分解挙動を解 析することを試みた.

試料には, PCLのカルボキシル末端側にベンジル基が 導入されたモデル試料を用いた. この試料は, 分子量を比 較的精密に制御しながら合成されたものである. フィルム 状に成形した試料を,Pseudomonas sp. 由来のコレステ ロールエステラーゼを含んだリン酸緩衝溶液に最大 36 時 間浸漬して，弚の酵素分解試験を行った.

Fig. 3 に, 酵素分解試験前後の PCL 試料の MALDI-
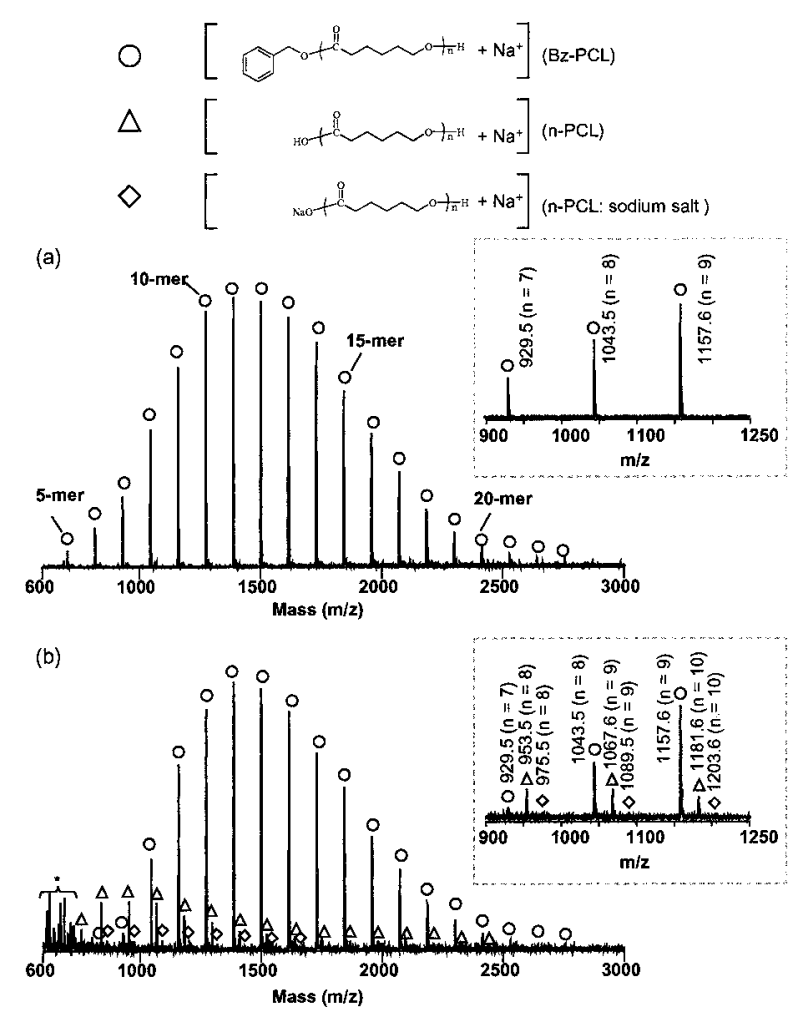

Fig. 3. Typical MALDI-MS spectra of (a) original PCL sample and (b) PCL sample recovered after the enzymatic degradation for $36 \mathrm{~h}$. Mass numbers in the expanded spectra indicate for monoisotopic mass.

MS スペクトルを示す．まず，Fig. 3(a) の酵素分解試験前 の PCL 試料の MALDI-MS スペクトルでは, 質量数 600 から 2,800 付近にかけて, 質量数 1,500 付近を極大とする 正規分布状の分子量分布か観測されている. このマススペ クトルから, この試料の数平均分子量 $\left(M_{n}\right)$ は 1,550 であ り, 多分散度は 1.06 であると求められた. また, 各ピーク の質量数から, この試料は, 末端にベンジル基をもつ PCL 成分 (Bz-PCL) が主成分であることか確認された.

次に, Fig. 3(b)に示した, PCL 試料を酵素分解処理した 後に回収された残存フィルムの MALDI-MS スペクトルを 見ると, 質量数 1,500 付近に分布の極大をもつ Bz-PCL の 分子量分布に加えて, 興味深いことに, 質量数 1,000 付近 を分子量分布の極大とする新たなピーク系列が現れてい る. このピーク系列の質量数から, これらは高分子鎖の末 端に水酸基とカルボキル基をもつ PCL 成分 $(n-\mathrm{PCL})$ であ ると帰属された。 もし，生分解の進行過程で高分子鎖内で のランダムな分解 (endo 型生分解) が起こっていれば, 残 存試料中の Bz-PCL 成分のピーク分布は低分子量側にシフ トするはずであるが，実際には，観測された Bz-PCL 成分 の分子量分布は, 生分解試験前のもの (Fig. 3a) とほとん ど変化していない，さらに，Py-GC を相補的に用いること によって，末端ベンジル基の相対濃度が，酵素分解試験の 時間経過とともに減少する樣子を定量的に解析することが できた. 以上の結果から，今回行った実験条件下では, ベ ンジル末端側から逐次分解が進行する「exo 型」の生分解 
反応が主として進行したことを，明らかにすることができ た。

\section{5. 非イオン系界面活性剤の新しい 生分解機構解析法の開発5), 6)}

オクチルフェノールポリエトキシレート $(\mathrm{OPEO})$ は, オ クチルフェノールとポリエチレンオキシド (PEO) が結合 した非イオン性界面活性剂（商標 Triton X) であり, 工業 用洗剂や農薬補助剂などの素材として多量に使用されてき た. OPEO が環境中に漏出すると, 微生物の作用により $\mathrm{PEO}$ 鎖部分が選択的に生分解され, 兴の結果, オクチル フェノール類や短鎖の OPEO および产の酸化物が環境中 に残存する. これらは, 内分泌かく乱作用か溞く疑われて いる，いわゆる「環境ホルモン」の一種である. 兴こで本 研究では, MALDI-MSを用いて, 土壤微生物による OPEO の生分解過程で生じる分解中間物の化学構造や分 子量分布の経時的な変化を観測し, 产の生分解機構を解析 することを試みた。

Fig. 4 に, 生分解試験前の試料 (a) と, 生分解試験を 48 時間行った試料 (b) に対して観測された MALDI マススペ クトルを比較して示す. まず, 生分解試験前の試料のマス スペクトル (Fig. 4a) では, OPEO のピーク群が, ナトリウ ムカチオン付加体 $[\mathrm{M}+\mathrm{Na}]^{+}$として, 質量数 400 から 1,000 付近にかけて正規分布状に観測されている. これに 対して，48 時間生分解試験を行った試料のマススペクト

(a)
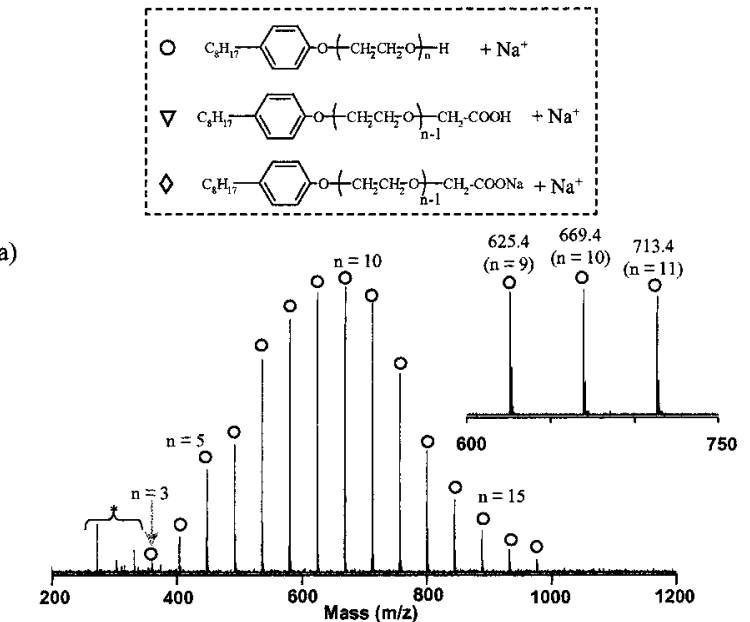

(b)

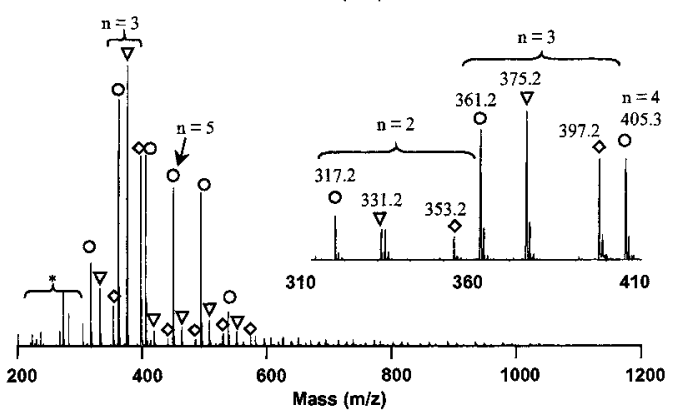

Fig. 4. Typical MALDI mass spectra of OPEO. (a) original sample, (b) the sample recovered after the incubation for $48 \mathrm{~h}$. *Corresponding to impurities and/or matrix peaks.
ル (Fig. 4b) では, 分子量分布は低質量数側へシフトして おり, 主鎖の分解がかな進行したことがわかる.さらに,

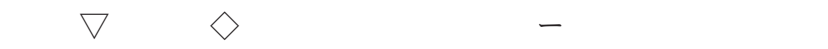
り，観測された質量数から，これらは試料分子の $\mathrm{EO}$ 鎖の 水酸基末端側がカルボキシル基に酸化された成分 (OPEC) および光のナトリウム塩 (OPECNa) のナトリウムカチオ ン付加体であると帰属された。この末端酸化物の生成か ら, Fig. 5 に示すように，末端水酸基側の酸化と乥れに続 くエーテル結合の加水分解が繰り返される exo 型の分解 機構によって生分解反応が進行したことを明らかにするこ とができた5).

この OPEC の生成機構を詳細に解析するために, 重酸 素 $\left({ }^{18} \mathrm{O}\right)$ でラベル化した水 $\left(\mathrm{H}_{2}{ }^{18} \mathrm{O}\right)$ を用いた培養実験を行 い, 分解中間物の化学構造を MALDI-MS て解析した. 兴 の結果，Fig. 6 に示すように，OPEC のカルボキシル基に ${ }^{18} \mathrm{O}$ か導入されることがわかり, バクテリアが水を利用し て OPEO の水酸基末端側を酸化している過程を詳細に解 析することができた. さらに，マススペクトル上に観測さ れる各成分ピークの同位体強度比を解析したところ，末端 酸化物のカルボニル酸素が溶媒の水とある程度の割合て酸 素交換反応していることがわかり，このことから界面活性

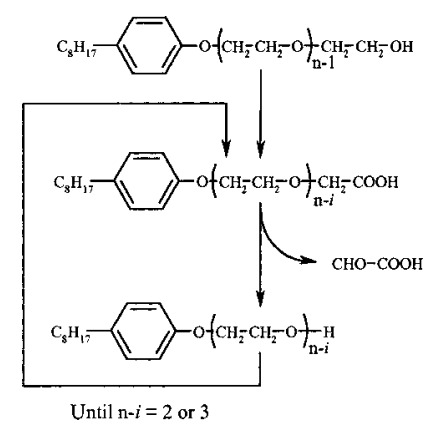

Fig. 5. Proposed biodegradation mechanism of OPEO.
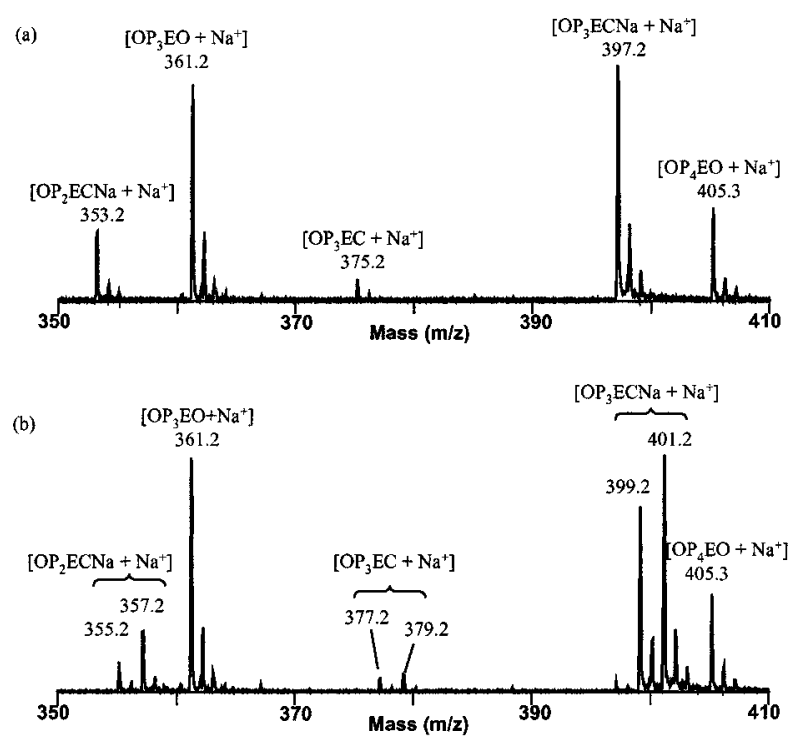

Fig. 6. Enlarged MALDI mass spectra (trimer region) of the biodegraded OPEO recovered after $48 \mathrm{~h}$ incubation using normal water (a) and ${ }^{18} \mathrm{O}$ labeled water (b). 
斉分子は分解酵素と共有結合を介したエステル中間体の形 成を経由して生分解されることが推測された

\section{6.おわりに}

高分子材料の特徵として, 腐食・分解されにくいことが 利点として挙げられるが，光のことが結果として廃棄物処 理問題などを引き起こす原因の一つにもなっている．弚の ため，環境中で微生物の作用によって分解される生分解性 高分子材料を利用することが，こうした問題を解決する手 段の一つであると考えられ，すでにいくつかの生分解生高 分子材料が実用化されている. しかしながら, 兴の材料が まずは生分解するのか否かに力点が置かれているのか現状 であり，弚の材料か実際に使用する環境中で，どのような 分解が起こるのか, さらに生分解の結果, 何らかの環境負 荷物質が新たに生じる可能性はないのか，などという「環 境調和」に関する研究は, まだ緒についたばかりである. 生分解性高分子材料の分解機構を分子レベルで詳細に解析 することによって，材料の環境適合性を評価し，弚の情報 を優れた材料の設計・開発へとフィードバックすること は, 今後, ますます重要視されていくものと考えられる. 筆者らは, 本稿て紹介したように, 熱分解分析法や質量分 析法などを相補的に用いて, 生分解性高分子材料の微細化 学構造と光の経時的な変化を総合的に解析する分析手法の 開発に取り組んでおり, 今後は, 兴の材料が使用される環 境の微生物相などとも関連づけて, 生分解性高分子材料の 環境適合性を評価する手法の開発へと発展させたいと考え ている.

謝 辞 以上の研究は, 博士後期課程に在籍していた名 古屋大学大学院工学研究科およひ博士研究員として在籍し ていた名古屋大学難処理人工物研究センターおよび名城大 学農学ハイテクリサーチセンターにおいて行ったものであ る.こ指導およびこ鞭撻を賜りました名古屋大学大学院工 学研究科の柘植 新名誉教授 (現 愛知工業大学教授) およ び大谷 肇助教授および名城大学の田村廣人助教授をはじ め, 共同研究者各位に深く感謝します.

\section{文献}

1) 佐藤浩昭, 大谷 肇, ぶんせき, 467 (2001).

2) H. Sato, M. Furuhashi, D. Yang, H. Ohtani, S. Tsuge, M. Okada, K. Tsunoda, and K. Aoi, Polym. Degrad. Stab., 73, 327 (2001).

3) 古橋資丈, 佐藤浩昭, 大谷 肇, 柘植 新, 岡田鉦彦, 中村 力也, 青井啓悟, 第 4 回高分子分析討論会講演要旨集, p. 84 (1999).

4) H. Sato, Y. Kiyono, H. Ohtani, S. Tsuge, H. Aoi, and K.
Aoi, J. Anal. Appl. Pyrolysis, 投稿中. b) 佐藤浩昭, 清野雄 介, 大谷 肇, 柘植 新, 古川裕美, 青井啓悟, 第 6 回高分 子分析討論会講演要旨集, p. 133 (2001).

5) H. Sato, A. Shibata, Y. Wang, H. Yoshikawa, and H. Tamura, Polym. Degrad. Stab., 74, 69 (2001).

6) H. Sato, A. Shibata, Y. Wang, H. Yoshikawa, and H. Tamura, Biomacromolecules, in press.

Keywords: MALDI-MS, Py-GC, Biodegradation, Polymer characterization

\section{PROFILE}

氏 名：佐藤浩昭

所 属: 独立行政法人 産業技術総合研究所 環境管理 研究部門

博士取得年：1998 年（工学博士）

取得大学：名古屋大学

主 査: 柘植新先生

趣 味：釣り（特に水上ワカサギ穴釣り），旅行，地図を 見ること, 家庭菜園

連絡先：干305-8569 茨城県つくば市小野川 16-1 (独) 産業技術総合研究所 環境管理研究部門 計測技術研究グループ（勤務先）

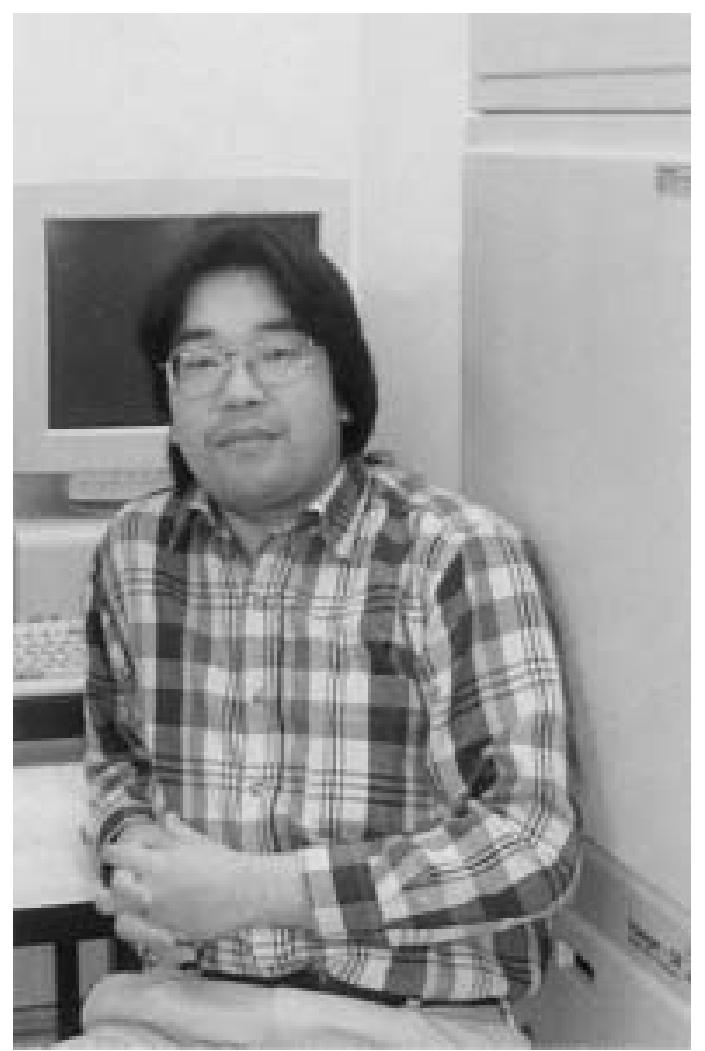

